\title{
Factors Militating Against Effective Planning of Secondary School Education in Taraba State
}

\author{
Iroegbu Abigail Ifeoma, \\ Federal University of Wukari, Taraba State, \\ Email id: Iroegbuabigeal@gmal.com \\ Revd Iroegbu Samuel Enyioma Ezechimere, \\ PhD Veenstra Theological Seminary, Donga Taraba State Nigeria, \\ Email id: samuelenyiomairoegbu@gmail.cm \\ Abashi Lydia Ebio* \\ Federal University of Wukari, Taraba State, \\ Email id: Lydiaabashi54@gmail.com
}

\begin{abstract}
Secondary school education is facing many problems such as shortage of professional teachers, inadequate instructional material, and funding, overcrowding and poor quality of educational performance. The problems have been linked to lack of effective planning of Secondary education as a panacea for academic excellence in the Northeast of Taraba. A survey research design was adopted for this study, using a structured questionnaire as data collecting instrument with one hundred and sixty respondents. Data collected were analysed using mean score. The study revealed that inadequate funding, inadequate data, shortage of professional planners, poor capacity development programme of planners,lack of planning materials, coupled with instability in the education policy and political upheavalsare the problem facing planning of secondary school in Taraba state. The study recommend that government should employ expertise in the educational sector, man-power periodic training and retraining for maximum planning and implementation of educational policies, regular data generation, analysis, prompt implementation, periodic evaluation reports, and priority to funding of educational planning
\end{abstract}

Keywords: Planning, Education, Problems, School, Secondary School.

\subsection{INTRODUCTION}

The responsibility for administering the education sector in Nigeria is shared among the federal, state and local governments. Thus, in the country's constitution, education is on the concurrent list, but the Federal Government is empowered to regulate all its sectors, engage in policy formation and ensure quality control. Also, the provisions of the constitution allow each tier of government to focus its responsibilities mainly on a sector of education. The Federal Government is involved directly in tertiary education. The states take care of secondary education, while the local governments handle primary education. Despite this arrangement, the Federal Government is expected to support the state and local governments in counterpart funding to enhance the quality of education in the country (NEEDS,2014).

The administration of the education system is shared mainly among the education ministries at the federal and state levels, as well as statutory bodies referred to as commissions. There are commissions established for different subsectors of the education system and are charged with various responsibilities 
for the subsectors. The Federal Ministry of Education is responsible for the coherence of the national policy and procedures and for ensuring that the states' policies operate within the parameters of the national policy as adapted for local needs (Moja, 2000). Coordination of policy at the political level is handled by the National Council of Education, the highest policymaking body chaired by the Federal Minister of Education and includes all the State Commissioners of Education. This body is advised by the Joint Consultative Committee on Education, which consists of all the Federal and State Directors of Education, Chief Executives of education statutory bodies, and Directors of University Institutes of Education (NEEDS, 2014).

The State Ministries of education which include Taraba state ministry of education are responsible for the development and implementation of educational policies, management and supervision of educational institutions in their respective states. Specifically, the responsibilities for maintaining all public elementary and secondary schools are vested in the education ministry. Such responsibilities include: determining the salaries of teachers; recruitment, appointment, promotion and discipline of staff; and provision of guidelines on the establishment of new schools and training and re-training of teaching and non-teaching staff. The oversight functions of the Ministry of Education are carried out through a number of agencies. For instance, the State Universal Basic Education Board (SUBEB) is responsible for the management of basic education, while the Teaching Service Commission takes charge of senior secondary education at the state level.

Secondary school education according to National policy on education (2014) is the education that children receive after primary education and before the tertiary education. Based on the 6-3-3-4 system of education, secondary education comprises six years duration, but given in two stages: a junior secondary school stage and a senior secondary school stage, each to run for three years duration. The Specific objectives of secondary school are to:

a. provide all primary school leavers with the opportunity for education of a higher level, irrespective of sex, social status, religion or ethnic background;

b. Offer diversified curriculum to cater for the differences in talents, opportunities and future roles;

c. Provide trained manpower in the applied science, technology and commerce at sub-professional grades;

d. Develop and promote Nigerian languages, art and culture in the context of world cultural heritage;

e. Inspire its students with a desire for self-improvement and achievement of excellence;

f. Foster national unity with an emphasis on the common ties that unite us in our diversity;

g. Raise a generation of people who can think for themselves, respect the view and feelings of others, respect the dignity of labour, appreciate those values specified under our broad national goals and live as good citizens;

h. Provide technical knowledge and vocational skills necessary for agricultural, industrial, commercial and economic development.

Emeka, (2014) observed that Secondary education plays a fundamental but complex role in preparing young people for the labour market, especially for people who leave secondary education for a job. Hence, an increasing number of young people in secondary education mean increasing diverse talents, diverse job interests and job opportunities. Unfortunately the objectives of secondary education have not been fully achieved in the state because student's desire for achievement and transition to tertiary institutions has become very low recently as a result of poor performances in the terminal examinations.

Emeka, (2014) disclosed that that students' performance in the West Africa Senior Secondary School 
Certificate Examination has been very poor over the years (below 16\%). Some of the challenges include inadequate teachers, inadequate funding, poor learning environment and infrastructure. This problem is linked to poor planning of secondary school education in the state. Educational planning in Nigeria have not been much attention by the government this why the educational planning system is engulfed with many challenges.

Ogunode, Gregory \&Abubakar, (2020) observed that the Nigerian educational planning system is ineffective due to lack of support by the government. The attitude of the Nigerian government to educational planning is not encouraging. Educational planners working in the various ministries and agencies of government are facing many challenges because the planning segment of the educational system is not been funded properly. This problem also apply to Taraba state. Educational system in the state is poorly planned and this is affecting the implementation of various programme and policies of education in the State. Based on this submission, this study is aimed to investigate the factors militating against effective planning of secondary School Education in Taraba State.

\subsection{Statement of the Problems}

Nigerian educational system is facing many problems and the problems include shortage of professional teachers, inadequate instructional material, inadequate funding, overcrowding and poor quality of education and the problems have been linked to poor planning of education. In Taraba state, the situation is not different especially in the secondary schools education which is also plagued with challenges of shortage of professional teachers,inadequate funding, lack of instructional materials, inadequate infrastructural facilities and poor quality of education. The Secondary school education in Taraba state is not performing well, the academic achievement of students is below average. Poor planning of secondary education in Taraba state have been identified as one of the major problem. It is against this background that this study is aim to investigate the factors militating against effective planning of secondary school education in Taraba state.

\subsection{Research Objectives}

The objective of this study is to find out the factors militating against effective planning of secondary school education in Taraba state. The specific objective is:

1) To find out if funding a problem affecting planning of secondary schools education;

2) To find out if inadequate data a problem affecting planning of secondary schools education;

3) To find out if inadequate professional planners a problem affecting planning of secondary schools education;

4) To find out if political instability a problem affecting planning of secondary schools education;

5) To find out if policies instability a problem affecting planning of secondary schools education;

6) To find out if corruption a problem affecting planning of secondary schools education;

7) To find out if lack of effective capacity programme of planners a problem affecting planning of secondary schools education; and

8) To find out if shortage of planning materials a problem affecting planning of secondary schools education.

\subsection{LITERATURE REVIEW}

Educational planning can be described as a process of making education decisions about future actions. It can be seen as a critique and readjustment of the present state of education so that the future may be influenced. It is a way of influencing the future of the education system by our actions of today 
(Noun,2012). Akpan, (2000) defined educational planning as the application of rational systematic analysis to the process of educational development with the aim of making education more effective and efficient in responding to the needs and goals of the learners and the society. This means that educational planning should take into account the needs of the pupils/students in terms of learning facilities and equipment, textbooks, classroom spaces and qualified educational personnel. In meeting the needs of the society, educational planning should take cognizance of the manpower, cultural, social and communication needs of the society (nation) as well as the economic changes (Akpan, 2000).

According to Noun (2012) the coverage of educational planning includes the following:

(i) Finance:- Educational planning is interested in the judicious use of funds allocated to education. It plans for revenue, handles costing and budgeting in education.

(ii) Personnel:- The adequacy in quantity and quality, training, the specialization, the trend in growth overtime constitute the part of education planning coverage.

(iii) Physical Resources:- The provision in quantity and quality of facilities, their utilization, their distribution and the general plant planning is within the ambit of educational planning.

(iv) Programmes and Services:- The organization, the patterns of activities and development overtime.

(v) Aims and Objectives:- The formulation, the expectations and aspirations, the expected outputs are parts of educational planning interests.

(vi) Alternative Decisions:- The preparation, which enables policy makers to make rational choices is an integral part of educational planning coverage. Ogunode, Gregory \&Abubakar, (2020) also disclosed that educational planning covers the sub-component of the educational system like manpower planning, school plant planning, infrastructural facilities planning, academic planning, lesson planning, financial planning for schools etc.

Ogunode, Gregory \&Abubakar, (2020) observed that there are many factors that determines the effectiveness of educational planning and some of the factors include; the attitude of the political office holder toward educational planning, the funds available for planning of education, the planning tools available, the number of educational professional planner, the level of capacity development for educational planners and political stability. Educational planning covers planning of the early child education, basic education, junior secondary education, senior secondary education and the higher education. Education administrators also plan for special education, gender education, mass education, adult education and science education etc.

There are many investigations on the challenges facing planning of education. Ogunode, Gregory \&Abubakar, (2020)carried out a research with the aims of assessing the political officeholder attitudes towards planning of education in FCT. The results revealed that there was significant relationship between the attitudes of political officeholders and poor planning of education in FCT. The finding revealed that the majorities of the respondents disagreed that political officeholders have positive attitude toward educational planning, majorities of the respondents disagreed that adequately funding are provided for educational planning. It was also discovered that majorities of the respondents disagreed that political officeholders are support the capacity development of educational planners and $100 \%$ of the respondents disagreed that political officeholders are providing necessary planning tools for educational planner to plan education.

Ololube (2013) who observed in Nigeria that educational system is encountering many significant impediments in terms of implementation and the educational system quality assurance in the last decades due to lack of effective planning. He identified shortage of accurate data, finances, qualified 
planners, poor national economic performance, unsuitable governing structure, interference and instability as responsible for low quality in educational planning.

Ogunode (2020) conducted a study that investigated the challenges facing the planning of Early Childhood Care, Development and Education [ECCDE] in Gwagwalada area council of FCT, Abuja, Nigeria. The result also revealed that the following are the challenges facing the planning of early child education programme in Gwagwalada area council of FCT, Abuja, Nigeria; inadequate data/information, inadequate funding of planning, inadequate planning tools, political influence, political instability, administrative bottleneck and poor capacity development programme for educational planners. The result also showed that the implication of challenges facing the planning of early child education programme in Gwagwalada is responsible for poor implementation of early child education programme in Nigeria.

Ogunode (2018) did study that investigated the challenges facing the planning of Basic Education in FCT, Abuja, Nigeria. Result collected and analyzed in the study showed that: $100 \%$ of the respondent agreed that there are challenges facing the planning of basic Education in FCT, Abuja, Nigeria and the challenges facing the planning of basic education in FCT includes; inadequate funding of planning, inadequate planning tools, inadequate educational planners, poor capacity of educational planners, political influences, political instability and lack of reliable data/information.

Victoria \&Owuama (2016) conducted a study that aimed at determining the constraints to planning and implementation of higher education programmes was carried out, with emphasis on the six higher institutions in Rivers State. The result of the study revealed among others that inadequacy of funds, planning without accurate statistical data, political influence, and misappropriation of funds and shortage of qualified manpower were major constraints. The findings also revealed that there were significant difference between male and female unit heads on the perception of constraints to planning and implementation of higher education programmes.

Ololube (2013) observed in Nigeria, educational system is encountering many significant impediments in terms of implementation and the educational system quality assurance in the last decades due to lack of effective planning. He identified shortage of accurate data, finances, qualified planners, poor national economic performance, unsuitable governing structure, interference and instability as responsible for low quality in educational planning. Poor planning of education is responsible for inadequate of teachers, shortage of infrastructural facilities, inadequate instructional materials, underfunding, poor implementation of educational programme and overcrowding.

Ogunode, (2020) did a study that investigated the challenges facing the planning of secondary schools education in the Federal Capital Territory (FCT) of Abuja, Nigeria. The result of the study showed; inadequate planning information, inadequate planning materials,poor educational planner training, political instability. Inadequate funding for planning activities and a shortage of professional educational planners are the challenges facing planning for secondary schools in FCT, Abuja, Nigeria.

\subsection{METHODOLOGY}

A survey research design was adopted for this study. This research work was carried out in Taraba state North East Nigeria. The state have sixteen local government. One hundred and sixty respondents were used for the study. The respondents were made up of senior education officers in charge of planning and administration. Purposive method was used to select the one hundred and sixty respondents. A structured questionnaire, titled the 'An Investigation Militating against Effective Planning of Secondary School Education Questionnaire' (IMAEPSSEQ) was used in obtaining information for the study. It is an open item questionnaire and is made up of two sections 'A and B'. Section A explained the rating scale and instructions to the respondents on how to fill the questionnaire, while section B was organised in clusters based on the four research questions of the study. It contains eight questionnaire items, and 
the response options with values assigned to them are: Strongly Agree (SA)...4; Agree (A)...3; Disagree (D)...2; Strongly Disagree (SD)...1. To ensure the face and content validity of the instrument, copies of the questionnaire were sent along with copies of the research questions and the purpose of the study to two experts in the Department of Educational Management and Policy, Taraba State University and to two expert on Measurement and Evaluation from the Department of Educational Foundations of the same university. They crosschecked the items in terms of clarity and adequacy in addressing the objectives and research questions. Their suggestions were used to produce the final draft of the questionnaire used in this study. The reliability of the instrument was determined through the test re-test method. Ten (40) copies of the instrument were administered to ten educational officers in a secondary school in Bauchi State and after an interval of two weeks, the questionnaire was re-administered to the same education officers. The scores of the first and second administrations were correlated using Pearson Product moment Correlation Co-efficient statistic and the correlation co-efficient value stood at 0.83 which was considered high enough to confirm the instrument reliable. Data collected by the questionnaire were analysed using mean score. The benchmark of fixed for the study was based on mean score of 2.5. Above 2.5 is accepted as significant and agreed while any score below 2.5 is considered rejected, not significant and disagreed.

\subsection{Result Analysis}

Table one To Find Out If Inadequate Funding is a Problem

\begin{tabular}{llllllll}
\hline Inadequate fund is a problem & F & SA & A & SD & D & X & REMARK
\end{tabular}

facing planning of secondary

$\begin{array}{lllllll}\text { schools160 } & 86 & 54 & 12 & 8 & 3.5 & \text { Agreed }\end{array}$

Table Two To Find Out If Inadequate Data is A Problem

$\begin{array}{llllllllll}\text { Inadequate data is a problem } & \mathrm{F} & \mathrm{SA} & \mathrm{A} & \mathrm{SD} & \mathrm{D} & \mathrm{X} & \text { REMARK }\end{array}$

facing planning of secondary

$\begin{array}{lllllll}\text { schools } 160 & 110 & 42 & 6 & 2 & 3.4 & \text { Agreed }\end{array}$

Table Three To Find out If Professional Planners is a Problem

$\begin{array}{llllllllll}\text { Inadequate professional planners } & \mathrm{F} & \mathrm{SA} & \mathrm{A} & \mathrm{SD} & \mathrm{D} & \mathrm{X} & \text { REMARK }\end{array}$
is a problem facing planning of

$\begin{array}{lllllll}\text { secondary schools } 160 & 92 & 47 & 11 & 10 & 3.2 & \text { Agreed }\end{array}$

Table Four To Find Out if Political Instability is a problem

$\begin{array}{lllllll}\text { Political instabilityF } & \text { SA } & \text { A } & \text { SD } & \text { D } & X & \text { REMARK }\end{array}$

is a problem facing planning of

$\begin{array}{lllllll}\text { secondary schools160 } & 73 & 58 & 15 & 4 & 3.0 & \text { Agreed }\end{array}$


Table Five To Find Out If Policies Instability is a Problem

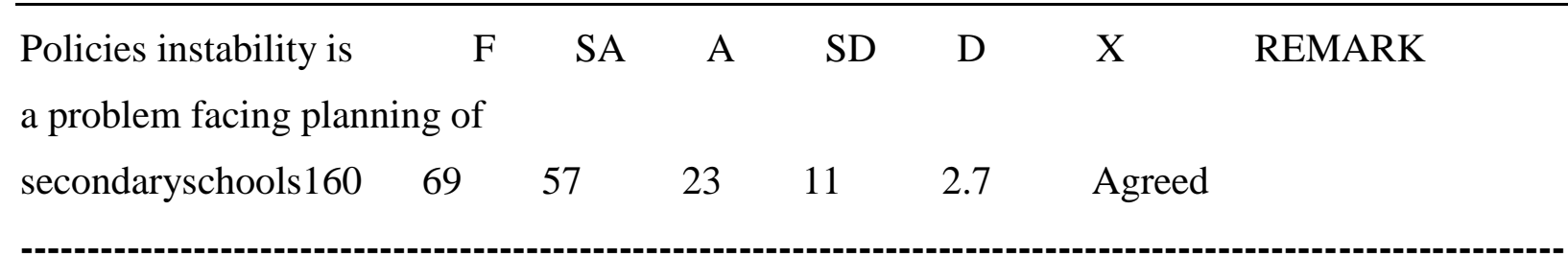

Table Six To find out if Corruption is a problem

$\begin{array}{llllllll}\text { Corruption is a problem } & F & \text { SA } & \text { A } & \text { SD } & D & X & \text { REMARK }\end{array}$

facing planning of secondary

schools160 $73 \quad 44 \quad 23 \quad 20 \quad 3.2$ Agreed

Table Seven To find out if poor capacity development programme is a Problem

$\begin{array}{lllllll}\text { Lack of effective capacity programme FSA } & \text { A } & \text { SD } & \text { D } & X & \text { REMARK }\end{array}$

of planners is a problem facing

$\begin{array}{lllllll}\text { planningof secondary schools160 } & 64 & 76 & 14 & 6 & 3.6 & \text { Agreed }\end{array}$

Table Eight To find out if Inadequate Planning Material is a Problem

$\begin{array}{llllllll}\text { Inadequate planning materialsF } & \text { SA } & \text { A } & \text { SD } & D & X & \text { REMARK }\end{array}$

is a problem facing planning of

$\begin{array}{lllllll}\text { secondary schools160 } & 75 & 44 & 21 & 19 & 2.9 & \text { Agreed }\end{array}$

Table 1 seeks to find out if inadequate funding is a problem facing the planning of secondary school in Taraba state. The result revealed the mean score is 3.5 which is more than the benchmark of 2.5 is hereby accepted as significant meaning that inadequate funding is a problem facing the planning of secondary school in Taraba state.

Response in Table 2 regarding if inadequate data a problem affecting planning of secondary schools education. The result collected showed that the mean score is 3.4 and is above the benchmark, so it is therefore accepted that inadequate data a problem affecting planning of secondary schools education.

Concerning table 3 , the mean score collected for if inadequate professional planners a problem affecting planning of secondary schools education is 3.4 and is above the bench mark of 2.5 meaning that inadequate professional planners is a problem affecting planning of secondary schools education in Taraba state.

In respect of table 4 that seek to know if political instability a problem affecting planning of secondary schools education. The result collected from the table is 3.0 and is above the cutoff point of 2.5. The result is accepted that political instability a problem affecting planning of secondary schools education in Taraba state.

Result on table 5 on if policies instability a problem affecting planning of secondary schools education obtained is 2.7. This is above the bench mark of 2.5 and is above the cutoff point and is therefore accepted as significant that policies instability a problem affecting planning of secondary schools 
education.

From Table 6, it can be seen that the majorities of the respondent agreed that corruption a problem affecting planning of secondary schools education with a mean score of 3.2 which is above the cutoff point of 2.5This implies that corruption a problem affecting planning of secondary schools education in Taraba state.

Responses on if lack of effective capacity programme of planners a problem affecting planning of secondary schools fetched responses that indicate most respondent agreed with a mean score of 3.6 which is above the cutoff of 2.5 . This indicated that lack of effective capacity programme of planners a problem affecting planning of secondary school.

To find out if shortage of planning materials a problem affecting planning of secondary schools education on table 8 got a mean score of 2.9 which is more than the cutoff point of 2.5 meaning that shortage of planning materials a problem affecting planning of secondary schools education in Taraba state.

\subsection{RESULT DISCUSSION}

The result collected from table one to table eight revealed that inadequate funding, inadequate data, inadequate professional planners, political instability, policies instability, corruption, lack of effective capacity programme of planners, shortage of planning materials are the problems affecting planning of secondary schools education in Taraba state. This findings is in line with the discovery of Ogunode (2018) whose result showed that: $100 \%$ of the respondent agreed that there are challenges facing the planning of basic Education in FCT, Abuja, Nigeria and the challenges facing the planning of basic education in FCT includes; inadequate funding of planning, inadequate planning tools, inadequate educational planners, poor capacity of educational planners, political influences, political instability and lack of reliable data/information. This findings also supported the result of Victoria \&Owuama (2016) who found out that inadequacy of funds, planning without accurate statistical data, political influence, and misappropriation of funds and shortage of qualified manpower were major constraints. The findings also revealed that there were significant difference between male and female unit heads on the perception of constraints to planning and implementation of higher education programmes.

\section{CONCLUSION}

The study concluded that inadequate funding, inadequate data, inadequate professional planners, political instability, policies instability, corruption, lack of effective capacity programme of planners, shortage of planning materials are the problems militating against effective planning of secondary schools education in Taraba state.

\section{Recommendation}

Based on the findings of this study, the following recommendation were put forward:

1) The government should ensure educational data are generated constantly in the ministry education Taraba state to allow educational planners have access to current data

2) The government should increase funding of the educational sector in Taraba state and more priority should be given to funding of educational planning;

3) The government should ensure educational planners are motivated and their working tools like calculating machines, planning software and computers are provided for them in their offices to aid effective educational planning in the country.

4) The government should employ more professional planners and deploy them to the ministries, departments and agencies in Taraba state; 
5) The government should monitor funds released for planning programme in all the ministries, department and agencies to avoid been diverted to private hands by officials in the ministries;

6) The government should develop a model that allows participation of all political actors in the country to participant in policy formulation and project planning so that the exit of one political party from office will not stop the implementation of the plan already done.

7) The government should ensure educational planners working in the ministries, agencies and department of education are constantly going for trained to boost their planning capacity.

\section{REFERENCES}

1. Abaidoo, A. E. (2017). Decentralised educational planning: A case study of two districts in Ghana. PhD Thesissubmitted to University of Sussex.

2. Akpan, C. P. (2000). Effective planning: a pre-requisite for successful implementation of the Universal Basic Education (UBE) scheme. International Journal of Research in Basic and Life-Long Education. 1(1\&2), 102-109.

3. Emeka, D, O (2014) The Challenges of Quality Secondary Education in Taraba State.

4. Federal Ministry of Education (2004): National policy of education, Lagos: NERDC

5. Moja, T. (2000). Nigeria Education Sector Analysis: An Analytical Synthesis of Performance and Main Issues. Report produced for the World Bank.

6. Noun (2009). Concepts and Theories of Educational Administration and Planning. Lagos, Nigeria.

7. NEEDS, (2014).Needs assessment in the Nigerian education sector. International organization for migration, Abuja, Nigeria.

8. Ogunode, N. J. (2020). Challenges of Planning Secondary School Education in Federal Capital Territory of Abuja, Nigeria. RUNAS. Journal of Education and Culture, 1(1), pp. 9-19

9. Ololube, N. P. (2013). The problems and approaches to educational planning in Nigeria: A theoretical observation. Mediterranean Journal ofSocial Sciences, 4 (12), 89.

10. Ogunode, N. J. (2020). Challenges facingthe planning of higher education in federal capital territory, Abuja, Nigeria.International Journal onIntegrated Education. 3(IV), 93- 109.

11. Ogunode, N., Gregory D., \&Abubakar, M. (2020). Assessment of political officeholders' attitudes towards planning of education in Federal Capital Territory, Abuja. Nigeria. Journal of Educational Research in Developing Areas, 1 (1), 68-79.

12. Ogunode N, J (2020)An investigation into the challenges facing the planning of early childhood care, development and education [eccde] in gwagwalada area council of fct, nigeria .Journal of Original Studies. Vol 1(2) P-85-98

13. OgunodeNiyi Jacob (2018) An Investigation of the Challenges Facing the Planning of Basic Education in FCT, Abuja, Nigeria. Electronic Research Journal of Behavioural Sciences, Volume 1(1) P-32-45

14. Victoria C. O, \&Owuama D, N (2016)Constraints in planning and implementation of higher education programmes in rivers nigeria European Scientific Journal 